\title{
SELF-INCRIMINATION AND THE STATES: RESTRIKING THE BALANCE
}

Ax the end of its recently concluded term the Supreme Court rendered two far-reaching decisions concerning the privilege against self-incrimination in the federal context. In Malloy $v$. Hogan ${ }^{1}$ a sharply-divided Court extended the fifth amendment privilege through the due process clause of the fourteenth amendment to bind states. In a companion case, Murphy v. Waterfront Commission, ${ }^{2}$ the Court reversed a state contempt decree against two defendants who, despite grants of state immunity, had refused to answer questions out of fear of federal incrimination. Holding that neither such state testimony nor its fruits could be used in a subsequent federal prosecution, ${ }^{3}$ the Court remanded the case to give the defendants an opportunity to reconsider their refusals to answer.

The Malloy decision is but another indication of the Court's awareness of the need to limit state power in order to protect the individual. It represents a logical step in the process of incorporating in the fourteenth amendment specific protections of the Bill of Rights. ${ }^{4}$ The step, moreover, is one supported

1. 32 U.S.I. WEEK 4507 (U.S. June 15, 1964).

2. 32 U.S.L. WEEK 4518 (U.S. June 15, 1964).

3. The Court's sweeping new rule demands that "a state witness may not be compelled to give testimony which may be incriminating under federal law unless the compelled testimony and its fruits cannot be used in any manner by federal officials in connection with a criminal prosecution against him." 32 U.S.L. WEEK at 4526.

4. This process has encompassed many of the basic liberties protected by the first eight amendments. Thus in Gideon v. Wainwright, 372 U.S. 335 (1963), the Court extended to state criminal proceedings the right to counsel guaranteed by the sixth amendment. Its language was indicative of its more active attitude toward the due process requirement:

We accept Betts $v$. Brady's assumption, based as it was on our prior cases, that a provision of the Bill of Rights which is "fundamental and essential to a fair trial" is made obligatory upon the States by the Fourteenth Amendment. We think the Court in Betts was wrong, however, in concluding that the Sixth Amendment's guarantee of counsel is not one of these fundamental rights.

Id. at 342.

Similarly, in Robinson v. California, 370 U.S. 660 (1962), the Court for the first time explicitly held the eighth amendment's prohibition against cruel and unusual punishment to be an essential protection which applied to state action through incorporation in the due process clause. True, the Court did not so treat its holding - it said merely that California, in jailing defendants convicted of dope addiction, inflicted "cruel and unusual punishment in violation of the Eighth and Fourteenth Amendments." Id. at 666. However, in the case which was relied upon for interpreting the scope of the due process clause, Louisiana $\varepsilon x$ rel. Francis v. Resweber, 329 U.S. 459 (1947), the Court had explicitly refused to decide whether due process included the eighth amendment. It was thus for the first time that the Court applied the protection to limit the state action in Robinson.

Finally, in a series of cases culminating in Mapp v. Ohio, 367 U.S. 643 (1961), the fourth amendment prohibition against unreasonable searches and seizures has been held to apply fully to the states through the due process clause of the fourteenth amendment. See also Wolf v. Colorado, 338 U.S. 25 (1949), applying the basic fourth amendment pro- 
by policy considerations basic to a system which values human dignity and self-respect. These basic values are embodied both in the fifth amendment privilege and in the concept of fundamental fairness represented by the due process clause of the fourteenth amendment.5

The Court's resolution of the tricky problems raised in the Murphy case, however, is less satisfactory. A series of decisions culminating in Feldman $v$. United States " had established the "dual sovereignty" doctrine. The doctrine held, simply, that the privilege against self-incrimination protects one only against the sovereignty questioning him; the local sovereign need not take cognizance of the danger of foreign prosecution. ${ }^{7}$

tection to state action, and Elkins v. United States, 364 U.S. 206 (1960), extending the federal exclusionary rule to bar from federal courts evidence illegally seized by state officials.

5. While the government constantly needs to gain information from individuals as a basis for maintaining order - see Comment, The Federal Witness Immunity Acts in Theory and Practice: Treading the Constitutional Tightrope, 72 YALE L.J. 1568 (1963) - its right to question is limited by the basic respect for human integrity inherent in democratic society. It cannot, consistent with this respect, humiliate its individual citizens by demanding that they disclose facts which may aid the state in establishing their own guilt. An analogy clearly illustrates the importance of this protection. A society callously disregarding human self-respect by forcing a man to press the button which electrocuted him would surely shock most sensibilities. Yet, as one commentator has pointed out, hailing an individual before a government organ and forcing his confession of crime or its elements, when another arm of the state will surely use the testimony to prosecute him, in effect demands that the individual inflict his own punishment. Such a demand is clearly inappropriate in a society based on respect for human dignity. See GrIswoLd, THE FIFTH AMendment Todax 7-10 (1955). And the same values which vitalize the privilege are the basis for the due process clause, "in" its protection of ultimate decency in a civilized society." Adamson v. California, 332 U.S. 46, 61 (1947) (Frankfurter, J., concurring).

The Court's resolution of the problem of standards to be applied by states is the only dubious portion of its opinion. In rejecting respondents' contention that "the availability of the federal privilege to a witness in a state inquiry is to be determined according to a less stringent standard than is applicable in a federal proceeding," the Court answered that "the same standards must determine whether an accused's silence in either a federal or state proceeding is justified." 32 U.S.L. WEEK at 4509 (emphasis supplied). If the Court meant that states could have no standards which in themselves offered less protection than that provided in federal courts, and that the only possible variations by states might be the addition of extra protections after the panoply of federal standards had been reproduced, its approach creates an unnecessarily rigid rule. For states might be able, by allowing departures from the federal scheme but compensating for them by new procedural safeguards, to offer the same quantum of protection afforded by the federal scheme. Certainly the advantage of state experimentation with new techniques of law enforcement is sufficiently great to warrant its protection. The Court's language in Malloy, therefore, is best interpreted as a guarantee that the quantum of protection afforded by federal standards must be met by states, rather than as a command of slavish adherence to federal procedures.

6. 322 U.S. 487 (1944). See also United States v. Murdock, 284 U.S. 141 (1931); Hale v. Henkel, 201 U.S. 43 (1906) ; Jack v. Kansas, 199 U.S. 372 (1905); Brown v. Walker, 161 U.S. 591 (1896).

7. See the statement of the doctrine in Murdock:

[F]ull and complete immunity against prosecution by the government compelling the witness to answer is equivalent to the protection furnished by the rule against 
The dual sovereignty doctrine, however, loses all theoretical justification once it has been determined that the self-incrimination privilege is binding on the states. For then it becomes a violation of the federal constitution for either the federal government or any state to force an individual to give information potentially leading to criminal conviction. ${ }^{8}$ Under the old doctrine, ${ }^{9}$ however, a state and the national government (or any two states) might, by immunity statutes, force an individual to accuse himself of crime. And to allow any two jurisdictions together to effect what no single jurisdiction could accomplish constitutionally would seem to defeat the purpose of the privilege. This might present no problem in a federal hearing, since the supremacy clause would probably make federal immunity binding on the states. ${ }^{10}$ But under traditional doctrine neither the states themselves nor the federal government need respect immunity granted by the laws of other states.

A practical justification for dual sovereignty can be argued, however, in terms of the states' need for broad powers of investigation to discharge more effectively their burden of regulating and preventing crime in the United States. ${ }^{11}$ Since a state cannot insulate a witness from foreign prosecution by a grant of immunity, ${ }^{12}$ the complete abandonment of the dual sovereignty doctrine would prohibit states from constitutionally compelling witnesses to give testimony which might incriminate under laws of other jurisdictions. This could well represent a serious limitation on the state's ability to investigate. ${ }^{13}$

The Court in Murphy recognized this important state interest, and accommodated it in the rule laid down. By barring subsequent use in another jurisdiction of the original testimony or its fruits, the Court was able to preserve the first sovereignty's right to compel testimony in exchange for immunity. ${ }^{14}$ An alternate approach in abolishing "dual sovereignty" would be to prohibit the questioning in the first instance because of the danger of subsequent in-

compulsory self-incrimination. ... As appellee at the hearing did not invoke protection against federal prosecution, his plea is without merit ....

284 U.S. at 149.

S. U.S. Const. amend. V, amend. XIV, \& 1.

9. See note 7 supra.

10. See Reina v. United States, 364 U.S. 507 (1960) ; Ullmann v. United States, 350 U.S. 422 (1956) ; Adams v. Maryland, 347 U.S. 179 (1954); Brown v. Walker, 161 U.S. $591,607-0 \mathrm{~S}$ (1896).

11. There seems little dispute over the proposition that the major burden of criminal law enforcement rests on the states. See Screws v. United States, 325 U.S. 91, 109 (1945); Abbate v. United States, 359 U.S. 187, 195 (1959) ; Rutkin v. United States, 343 U.S. 130, 141-42 (1942) (dissenting opinion); Rogge, Compelling the Testimony of Political Deviants, 55 Mrce. L. REv. 163, 177 (1956). And the power of investigation is clearly basic to discharging this burden. Cf. Comment, 72 Yale L.J. 1568 (1963).

12. See Knapp v. Schweitzer, 357 U.S. 371 (1958) ; Jack v. Kansas, 199 U.S. 372 (1905).

13. For a good, detailed statement of this view see Brief for Nat'l District Attorneys' Assoc. as Amicus Curiae, Malloy v. Hogan, 32 U.S.L. WeEk 4507 (June 15, 1964).

14. 32 U.S.L. WEEK at 4526. 
crimination. This would represent the most airtight protection of the individual. ${ }^{15}$ But the Court's approach is clearly preferable, at least in theory: The detriment to individual dignity, as represented in the privilege, is negligible, since none of his testimony or its fruits may be used to harm him. Simultaneously, an important state interest - that of information-gathering ${ }^{16}$ - is effectively protected. State courts and legislative committees are enabled, by granting local immunity, to extract answers without being forced to investigate the possibility of foreign prosecution ${ }^{17}$ or having to wonder if their immunity statutes can have extra-territorial effect. ${ }^{18}$ Further, another important interest involved in the dual sovereignty situation - that of a second sovereignty desiring subsequently to prosecute the witness - is also theoretically protected by the Murphy decision. The rule, after all, does not bar all subsequent prosecutions, ${ }^{19}$ but only those derived from the compelled testimony. While this rule restricts the ability of foreign states and the federal government to prosecute, it eliminates only that evidence produced by a witness's self-incriminatory testimony, in itself a mere windfall for any prosecuting jurisdiction, which could not itself have forced such disclosures. ${ }^{20}$

The Court's formulation in Murphy is thus theoretically perfect. It is subject, however, to one fatal objection: it is unworkable. The theoretical deference to the second jurisdiction's interest in prosecuting is illusory. The Court made clear that subsequent prosecutions would still be permitted where the prosecutor did not rely on the original testimony or leads obtained from it. But the Court also explicitly stated that:

Once a defendant demonstrates that he has testified, under a state grant of immunity, to matters related to the federal [or second state] prose-

15. Clearly the protection against being compelled to convict oneself is most completely effectuated if one is allowed to refrain from answering at all where incrimination is a reasonable possibility. This view was a popular one prior to the Mutrphy decision. See Hutcheson v. United States, 369 U.S. 599, 624 (1962) (dissenting opinion) ; Knapp v. Schweitzer, 357 U.S. 371, 383 (1958) (dissenting opinion) ; Kroner, Self-Incrimination: the External Reach of the Privilege, 60 CoLum. L. Rev. 816 (1960); Grant, Federalism and Self-Incrimination, 4 U.C.L.A.I. REv. 549 (1957).

16. See note 11 supra.

17. This problem would be a significant one. State courts would be almost impossibly burdened if possible foreign incrimination gave a complete right to silence. Since the claimant of the privilege would be free of the obligation to justify his claim [Under Hoffman v. United States, 341 U.S. 479 (1951), as incorporated by Malloy], the court would have to survey all state and federal laws in each case before it could be certain that a given claim was frivolous. See 8 WIGMORE, EVIDENCE $\$ 2258$, at 338-39 (3d ed. 1940). The impossibility of such a task could result in the success of almost any claim of privilege, and thus in considerable abuse.

18. These statutes have no such effect. See note 12 supra.

19. The opinion of the Court in Murphy clearly recognizes the possibility of subsequent prosecution of witnesses for crimes related to their testimony. See 32 U.S.L. WEEK at 4526 n.18. 
cution, the federal authorities have the burden of showing that its evidence is not tainted by establishing that it had an independent, legitimate source for the disputed evidence. ${ }^{21}$

It would seem virtually impossible to discharge this burden of showing that testimony known to an investigator did not influence him in conducting a search for evidence upon which to base a prosecution. Any court faced with such facts will probably find, in most cases, that the prosecutor has failed to sustain that burden. Even in situations where a prosecutor was preparing or had commenced an investigation, it would be difficult to show that testimony about which he knew or should reasonably have known did not influence the direction taken by his investigation. And where no investigation had been undertaken before a witness testified, and investigation leading to prosecution was then commenced, the burden could not be realistically discharged. The resulting crippling limitation on the ability to prosecute could be more dangerous than a limitation on the ability to investigate. ${ }^{22}$

If states conducting investigations and witnesses testifying before them were sensitive to this problem, or if the witnesses to whom immunity was granted were uniformly of little importance from the viewpoint of foreign prosecutors, the problem would be of relatively minor significance. But these eventualities

20. Under the philosophy of Malloy, if the privilege were guaranteed to all witnesses, state or federal, clearly no prosecutor could force incriminatory disclosures and then use them as the basis for prosecution. See 32 U.S.L. WEEK 4507-08. It was this decision which forced abandonment of dual sovereignty in Murphy. See 32 U.S.L. WEEK at 4519.

The theoretical accommodation of all interests by this approach was doubtless the basis for the numerous suggestions to adopt it which preceded Murphy. See Knapp v. Schweitzer, 357 U.S. 371, 382-85 (1958) (Black, J., dissenting) ; Danforth, Another Feldman Another Day, 29 Geo. WASE. L. Rev. 75 (1960); Comment, 55 Nw. U.L. REv. 110, 120 (1960); $c f$. Note, 68 Y ALE L.J. 322, 332-34 (1958).

21. 32 U.S.L. WEEK at 4526 n.18. This rule would be analogous to that used to regulate statutory violations of the wiretap acts - once an improper act on the part of the government is proved (here a compulsion to testify), the burden shifts to it to prove that all or the remainder of its evidence has not been derived from the act. United States v. Coplon, 185 F.2d 629, 636 (2d Cir. 1950); United States v. Goldstein, 120 F.2d 485, 488 (2d Cir. 1941), aff'd, 316 U.S. 114 (1942). Cf. United States v. Lipshitz, 132 F. Supp. 519, 522-23 (E.D.N.Y. 1955). A significant distinction exists between the two cases, however; the second sovereignty in a dual sovereignty case is guilty of no misconduct equivalent to that of the sovereignty in wiretap cases. Rather than being saddled with a proof burden due to its own act, the prosecuting sovereign in a dual sovereignty case must discharge a burden which the acts of another, the investigating jurisdiction, have imposed on it.

22. While a limit on investigation can be onerous, necessary information may still be obtained by other avenues. When the right to prosecute at all is foreclosed, however, as the burden of proof demands, criminals are simply left at large. Yet this result is demanded by a rule which would accomplish the work of the privilege itself. $C f$. Counselman v. Hitchcock, 142 U.S. 547, 586 (1892) ; Comment, The Scope of Statutory Immunity Required by the Fifth Amendment Self-Incrimination Privilege, 57 Nw. U.L. REv. 561, 563-64 (1962). 
are uncertain and, indeed, unlikely. Witnesses surely will not willingly cooperate with officials likely to prosecute them. And there is substantial evidence, from earlier federal experience, that witnesses in fear of prosecution are far less concerned with self-defamation than with avoiding imprisonment for their misdeeds. ${ }^{23}$ "Immunity baths," ${ }^{24}$ in which witnesses who are likely targets for federal or state prosecution would attempt general confessions, may be expected. There seems little reason to expect significantly more sympathy from local state officials than from witnesses themselves. The motives of state prosecutors or investigators will often be unrelated to any foreign state or federal interest, ${ }^{25}$ and circumstances sometimes arise in which the local state's interests will be opposed to those of other jurisdictions. It is unreasonable to expect state officials to be sensitive to the demands of other jurisdictions, especially when there is some strong motive impelling them to demand information. And these situations may often concern individuals whom other jurisdictions are anxious to prosecute. The dual sovereignty cases themselves exhibit the desire of officials in other jurisdictions to conduct such prosecutions. In the Feldman ${ }^{26}$ case, for example, the defendant had been questioned in a New York proceeding to ascertain his assets as a judgment debtor: his answers revealed that he had used the mails in a scheme to defraud, for which federal prosecution was instituted. ${ }^{27}$ And many other examples in which two jurisdictions' legitimate interests would clash even more violently might also be suggested. Thus an obstreperous Southern state legislature could "investigate" election activities within the state to gain the testimony of officials who had interfered with the right to vote in violation of the Civil Rights Acts. ${ }^{28}$ If such testimony were given, any subsequent federal prosecution would be severely hampered. ${ }^{29}$

23. Comment, 72 Yare L.J. 1568, 1572 (1963).

24. Ibid.

25. Thus state and federal statutes may govern similar conduct for differing reasons. Payments to labor officials in New York, for example, may constitute a violation of N.Y. Penal LAW $\S 380$, concerning extortion, whose enforcement is based on local police considerations, while the same payments are regulated by $\$ 302$ of the Taft-Hartley Act, 61 Stat. 157 (1947), 29 U.S.C. $\$ 186$ (1958), for vastly different reasons. See Knapp v. Schweitzer, 357 U.S. 371 (1958).

26. 322 U.S. $487,488-89$ (1944).

27. Similarly, in Commonwealth $\nabla$. Rhine, 303 S.W.2d 301 (Ky. 1957), the Kentucky case in which extraterritorial effect was given to the state privilege, defendant had been asked questions concerning his associations. The answers could have spurred a federal prosecution under the Smith Act, 18 U.S.C. \$ 2385 (1958), which was being vigorously enforced during the 1950's. See ENIERson \& Haber, Political aNd CiviL Rights in the UNITED STATES 371-72 (2d ed. 1958).

28. 18 U.S.C. $\$ 242$ (1958).

29. Examples of state against state conflict are equally easy to conceive. Thus a state in investigating an interstate crime ring may grant immunity to an individual whose local activities are insignificant but whose interstate activities make him a prime target for an- 
In rejecting the Court's solution in Murphy as unworkable, great weight is being given here to the state interest in criminal prosecution and administration. The Court in Malloy, however, rightfully overrode such interests in deciding the general question of the applicability of the fifth amendment to the states. ${ }^{30}$ It is submitted that the interests involved in Malloy and Murphy differ substantially, and that the resultant balance struck between state and individual interests need not and should not be the same in the two cases.

In the first place, the Malloy rule, applying the self-incrimination privilege against the states, does not substantially interfere with the demands of local criminal administration. True, the state clearly has an interest in the gaining of information in legislative or special grand jury hearings on subjects of public interest and at trial as to the facts of crime. ${ }^{31}$ In the legislative setting, however, gaining information for probable legislation, and not the entrapment of criminals, is the purpose of investigation. ${ }^{32}$ Guaranteeing the privilege against state action, therefore, need have no adverse effect on legislative efficiency. If the desired information is of significance to the state, an appropriate immunity statute can be invoked - or enacted if one does not exist ${ }^{33}$ and the witness may be forced to answer any relevant questions. ${ }^{34}$ Of course, to the extent that an investigation is a guise for an attempt to expose and prosecute criminals by forcing them to admit crimes, immunity statutes would not ease the burden imposed on interrogators as a result of the incorporation of the privilege. But it would seem outrageous to withhold protection of the privilege for the purpose of exposing criminals to trickery by state investigators. $^{35}$

On the other hand, the interest of states in forcing testimony by the accused at trial might appear to be a significant obstacle to incorporation. Still, al-

other state's prosecution; he may answer questions revealing the nature of his foreign activities to a significant extent, eliminating the possibility of a subsequent foreign prosecution.

30. It held that "the same privilege" which protects federal witnesses and defendants is applicable to state proceedings. 32 U.S.L. WEEK at 4508 . See note 5 supra.

31. See note 5 supra.

32. Comment, 72 Y ALE L.J. 1568 (1963).

33. States appear to have no reluctance to enact immunity statutes. Each has enacted numerous statutes to fit the needs of local administration. See 8 WIGMORE, EvideNCE $\S 2281$ n.11 (3d ed. 1940).

34. The privilege is satisfied if a witness is protected against a reasonable possibility of subsequent prosecution growing out of his testimony. Counselman v. Hitchcock, 142 U.S. 547 (1892) ; Brown v. Walker, 161 U.S. 591 (1896). Very few cases are likely to arise in which states could not grant constitutionally sufficient immunity, except in dual sovereignty situations. See Jack v. Kansas, 199 U.S. 372 (1905) ; Knapp v. Schweitzer, 357 U.S. 371 (1958).

35. This especially seems true given the purpose underlying the due process clause and the standards for applying it. See note 5 supra. 
though some commentators on the law of evidence have criticized use of the privilege to cut off vital sources of information, ${ }^{36}$ the growing improvement in techniques for investigating and solving crimes makes the use of forced selfaccusation far less imperative than it may have been when these critics wrote. ${ }^{37}$ And the interest of the state in orderly criminal administration and familiar procedures is hardly jeopardized by incorporating the privilege, since all states already guarantee the privilege to some extent. ${ }^{38}$

In the Murphy situation, however, a different set of interests is involved. A new factor, the interest of the second, prosecuting sovereignty, must be considered along with those of the information-gathering sovereignty and the individual. Generally, the prosecuting interest is more strongly felt than the information-gathering interest $;^{30}$ in many cases the interest of the second jurisdiction will be greater than that of the first. ${ }^{40}$ Further, as demonstrated above, the Murphy rule, while adequately protecting both the individual's and the interrogator's interests, obstructs to a great extent the prosecutor's ability to discharge his societal function. ${ }^{41}$

Such a result is both undesirable and unnecessary. This important prosecutorial interest can be accommodated consistently with broader protection for the individual — though admittedly short of the complete protection envisioned in Murphy - than existed under the dual sovereignty rule. Thus while the extended exclusionary rule derived from abolishing Feldman may prove harmful, the actual holding of Feldman, that testimony compelled in a state hearing could be used as evidence in a federal prosecution, ${ }^{42}$ was rightly overruled. For introduction of such testimony seems the harshest possible undercutting of the

36. The accused is, after all, more likely than any other to know the degree and circumstances of his involvement in the crime with which he is charged. 8 WIGMoRE, EvrDENCE § 2251 (3d ed. 1940); MCCORMICK, EvIDENCE $\$ 136$ (1954).

37. Indeed, this shifting balance of power between state and individual has increased the need for more positive aids to the individual such as criminal discovery. See, e.g., Louisell, Criminal Discovery - Dilemma Real or Apparent?, 49 CaLrF. L. REv. 56, 87 (1961). It is used as the basis for proposed rules on defendants' criminal discovery of state's evidence. See Fletcher, Pretrial Discovery in State Criminal Cases, 12 Stan. L. REv. 293, 305 (1960).

38. All but two states have self-incrimination guarantees in their state institutions. 8 WIGMORE, EVIDENCE $\$ 2252$ n.3 (3d ed. 1940). And the others guarantee it by statute. Iowa Code ANn. § 622.14 (1954); N.J. Stat. ANN. 2A 84A 17-18 (Supp. 1963). Iowa, significantly, interpreted the privilege into its constitution's due process clause long before it was enacted by statute. State v. Height, 117 Iowa 650,91 N.W. 935 (1902). The lack of uniform standards, however, made the incorporation question hardly a moot one. In. deed, the application of federal standards in Malloy was the basis for reversal. 32 U.S.L. WEEK at 4509-10.

39. See note 22 supra.

40. See notes 28 and 29 supra and accompanying text.

41. See text accompanying notes 21 and 22 sipra.

42. 322 U.S. $487,493-94$. 
purpose of the privilege. If, by affording the privilege, society has decided that it is inconsistent with human dignity for a government to force an individual to convict himself, and that it is fundamentally unfair to subject him to penalty for failing to do so, it hardly seems that society can, consistent with that decision, introduce testimony compelled in one jurisdiction as evidence to convict in another. ${ }^{43}$ It is, no doubt, somewhat inconsistent with this policy even to use the fruits of such testimony in a subsequent foreign proceeding, despite the fact that this extension of the privilege, as noted above, ${ }^{44}$ is in practice unworkable. But disallowing introduction of the testimony itself obviously a less severe hindrance of state criminal administration ${ }^{45}$ - would at least eliminate the most blatant incursion on the policy of the privilege.

Of course, the possibility would remain that the fruits of a witness's testimony could be used against him in a subsequent foreign proceeding. While this possibility cannot be entirely eliminated due to the practical demands of law enforcement noted earlier, ${ }^{46}$ some protection can be afforded. Overruling United States $v$. Murdock ${ }^{\mathbf{4}}$ is a step in that direction, to the extent that Murdock held foreign prosecution wholly irrelevant to a claim of the privilege; taking account of foreign prosecutions is consistent, moreover, with the approach used by those states willing to give extraterritorial effect to their local privilege. ${ }^{48}$ Following the lead indicated by most of the states extending the

43. See note 5 supra. If it is inconsistent with the amendment's spirit to force an answer where defendant may reasonably fear danger, even though not immediate, from replying [see Hoffman v. United States, 341 U.S. 479, 486-87 (1951)], it is far more inconsistent to allow an individual's compelled answer to be read into the record against him in a subsequent hearing. Such a practice is pure, compelled self-accusation. This argument obviously assumes compulsion of the first answer; if the privilege is waived, as it can easily be [see, e.g., Rogers v. United States, 340 U.S. 367, 377 (1951)] no problems arise.

44. See text accompanying notes 21-29 supra.

45. Prior testimony used as evidence would unquestionably be a pure windfall for a subsequent prosecutor. He could in no way have compelled the evidence without granting immunity. All the rule requires of him is that he discover sufficient evidence to prosecute without the direct help of the prospective defendant, which he would have had to do if the defendant had never testified in the first place. It should also be noted that this rule furthers a policy which some commentators have proposed in justification for the privilege - the maintenance by prosecutors of high standards of operation and effectiveness through the closing off of easy, slipshod roads to gaining convictions. See 8 McCorancr, EVIDENCE $\$ 136$, at 289 (1954).

46. See text accompanying notes $21-29$ supra.

47. 284 U.S. 141 (1931).

48. Several states had extended application of their local privilege prior to the Murphy ruling. Thus, the Supreme Court of Michigan held in People v. Den Uyl, 318 Mich. 645, 29 N.W.2d 284 (1947), that a witness who was under federal indictment was not obliged to testify in a state proceeding, even when granted state immunity, since his testimony would obviously aid in the federal prosecution:

Holdings [that the privilege covers foreign incrimination] ... are essential to render fairly effective the quoted State constitutional provision against self-in- 
reach of the privilege, the reference by a witness to a pending or imminent ${ }^{40}$

crimination. It seems like a travesty on verity to say that one is not subjected to self-incrimination when compelled to give testimony in a State judicial proceeding which testimony may forthwith be used against him in a Federal criminal prosecution.

318 Mich. at 651,29 N.W.2d at 287.

Louisiana similarly held, in State ex rel. Doran v. Doran, 215 La. 151, 39 So. 2d 894 (1949), that a witness being cross-examined on a matter not strictly related to his purpose in testifying could claim the privilege as to the unrelated issue, because of an indictment pending in California. The doctrine announced was considerably circumscribed in subsequent cases, however. See State v. Ford, 233 La. 992, 99 So. 2d 320 (1958).

Similar decisions had been rendered in Kentucky, Pennsylvania, and Florida. In Commonwealth v. Rhine, 303 S.W.2d 301 (Ky. 1957), the Kentucky Court of Appeals held that its constitutional provision protecting against self-incrimination applied to a possible federal prosecution and the court applied federal standards to determine how it should treat a claim of the privilege and what answers might be incriminatory. In Pennsylvania, a pending federal indictment was held by a county court sufficient ground for a claim of state privilege. Altieri v. Pennsylvania Coal Co., $25 \mathrm{~Pa}$. D. \& C.2d 714 (County Ct. 1961); see also Putnik Travel \& Tourist Agency v. Goldberg, 17 Pa. D. \& C.2d 590 (County Ct. 1958). And Florida declared not only that its self-incrimination privilege protects against incrimination under foreign law where prosecution is likely, but that its constitution protected against the state's use of self-incriminatory information given involuntarily in a federal proceeding. State v. Kelly, 71 So. 2d 887 (Fla. 1954). See also Lorenzo v. Blackburn, 74 So. $2 \mathrm{~d} 289$ (Fla. 1954).

In three states similar statutory protection had been extended to witnesses. In Illinois, the statute provides that a claim of privilege is good and immunity statutes are inapplicable where foreign prosecution is possible, and federal standards are used for interpreting the right. Ilz. Rev. Stat. 38:580(a) (1953); see People v. Burkert, 7 I1l. 2d 506, 131 N.E.2d 495 (1955). And similar, if less sweeping, statutes had been enacted in California and New Jersey. Cal. Penal Code $\$ 1324$ (Supp. 1963) (applies in felony proceedings only - not yet construed) ; N.J. Rev. Stat. 2A :84A-18 (Supp. 1963) [clear justification for claim necèssary, In re Boiardo, 34 N.J. 599, 170 A.2d 816 (1961); see also In re Waterfront Commission, 39 N.J. 436, 189 A.2d 36 (1963)]. The cases in Michigan, Florida, Louisiana and Pennsylvania, broadening application of the local privilege, have, however, extended allowance of invocation only when foreign prosecution was pending or imminent. In the leading Michigan case, for example, federal indictment was pending, and other Michigan opinions have been couched in cautious language noting and condemning the possibilities of abusing the privilege. See In re Watson, 293 Mich. 263, 284, 291 N.W. 652, 661 (1940). And in the remaining three states, claims of privilege have been rejected on the ground that federal prosecution was not pending or imminent. E.g., State v. Kelley, 71 So. $2 d 887$ (Fla. 1954); State v. Ford, 233 La. 992, 99 So. $2 d$ 320 (1956).

49. If no pending prosecution could be pointed to, the witness would have the burden of showing by clear and convincing evidence that a proceeding was to be instituted. $\mathrm{He}$ might thus be required to point to public declarations of intent to prosecute him by some foreign official or a foreign sovereign's announced campaign against offences related to the present local investigation, which clearly was likely to direct itself at the witness very soon. This extra requirement on witnesses in dual sovereignty cases - which does not exist in single sovereignty cases - see Malloy, 32 U.S.I. WEEK at 4510 - is not only practically necessary, but to some extent theoretically justifiable. The most important 
federal or state proceeding against him would be grounds for a legitimate assertion of privilege. The court in each case would, of course, still be free under the rationale of Hoffman $v$. United States ${ }^{50}$ to determine, as in general claims of the federal privilege, whether under all the circumstances the witness could have a reasonable fear that his testimony would be used in a foreign action. ${ }^{\text {s1 }}$ If so, he would be entirely insulated from forced self-accusation; if not, the court could then compel his answer. And such a decision would not constitute a violent break with precedent, since cases prior to $M u r d o c k$ rested on the ground that foreign prosecution was highly unlikely and therefore irrelevant.52

In one important area, however, the Murphy rule is appropriate. Where the two sovereignties involved are actively cooperating in attempting to prosecute or extract information from an individual, the fruits of his testimony should be excluded along with the testimony itself. ${ }^{53}$ In such cases, after all, the interests of the sovereignties are the same, and the reason for treating the case differently from Malloy therefore vanishes. ${ }^{54}$

The Court in Murphy was correct in abolishing the anomalous doctrine of dual sovereignty. But it went too far in holding fruits of compelled testimony as well as the testimony itself protected in all cases from subsequent prosecutorial use. ${ }^{55}$ Two steps, however, can be taken, consistent with the demands of orderly criminal administration, to gain greater protection for witnesses in situations where multiple prosecutions pend: a claim of privilege can be allowed where a second related federal or state prosecution is pending or clearly imminent, and an exclusionary rule can be applied to bar from subsequent prosecution testimony rendered under compulsion. These two steps, combined

circumstance to which a court must look when privilege is claimed is the likelihood of future prosecution based on testimony which the recalcitrant witness might give. It is clear that future prosecution by a foreign state based on testimony offered in a hearing is as a general rule far less likely than local prosecution growing from the same answer. Requiring a preliminary showing of reasonable foreign danger by the witness is thus not entirely consistent with the approach of single sovereignty cases.

50. 341 U.S. 479 (1951).

51. Id. at $486-87$.

52. See Murphy v. Waterfront Comm'n, 32 U.S.L. WEEK at 4524.

53. The Court implied that it was willing to allow this exception to Feldman long before it was willing to adopt the sweeping approach of Murphy. Knapp v. Schweitzer, 357 U.S. 371, 380-81 (1958) ; Feldman v. United States, 322 U.S. 487, 494 (1944); see Byars v. United States, 273 U.S. 28 (1927).

54. The great danger implicit in the broad rule of Murphy (see text accompanying notes 21-29 supra) does not appear in this limited situation. The clash of federal and state (or two state) interests feared in other cases is unlikely, and, in any case, irrelevant where collaboration exists between the two jurisdictions involved or where one deliberately instigates investigation by the other.

55. Any attempt to limit the Court's holding appears foredoomed. The opinion's language is broad and clear in requiring full self-incrimination protection in the dual sovereignty context. See note 3 supra. 
with the Malloy holding that the privilege is essential to due process and therefore demanded of the states, would go as far as possible toward fulfilling the policy of the self-incrimination privilege in upholding individual integrity without unduly burdening state criminal procedures. 